\title{
НОВЫЕ КОНЬЮГИРОВАННЫЕ ФОТОСЕНСИБИЛИЗАТОРЫ ДЛЯ КОМБИНИРОВАННОЙ ПРОТИВООПУХОЛЕВОЙ ТЕРАПИИ
}

\author{
А.Ю. Федоров' ', В.Ф. Отвагин', А.В. Нючев', Н.С. Кузьмина', \\ Л.В. Крылова², И.В. Балалаева \\ ${ }^{1}$ Кафедра органической химии, ННГУ им. Н.И. Лобачевского, \\ 603022, Россия, Нижний Новгород, пр. Гагарина, 23. \\ ${ }^{2}$ Кафедра биофизики, ННГУ им. Н.И. Лобачевского, \\ 603022, Россия, Нижний Новгород, пр. Гагарина, 23.
}

DOI: 10.19163/MedChemRussia2021-2021-58

E-mail:afedorovnn@yandex.ru

Важнейший тренд в создании новых препаратов для фотодинамической терапии - конъюгирование фотосенсибилизаторов с различными молекулами, имеющими собственную фармакологическую активность. Нами были предложены и синтезированы различные типы таких конъюгатов, состоящие из порфириноидов природного или синтетического происхождения, связанных через расщепляемые линкеры с ингибиторами тирозинкиназ или антимитотическими препаратами (Схема 1) [1, 2]. Для полученных комбинированных соединений проведены исследования противоопухолевой активности in vitro / in vivo.

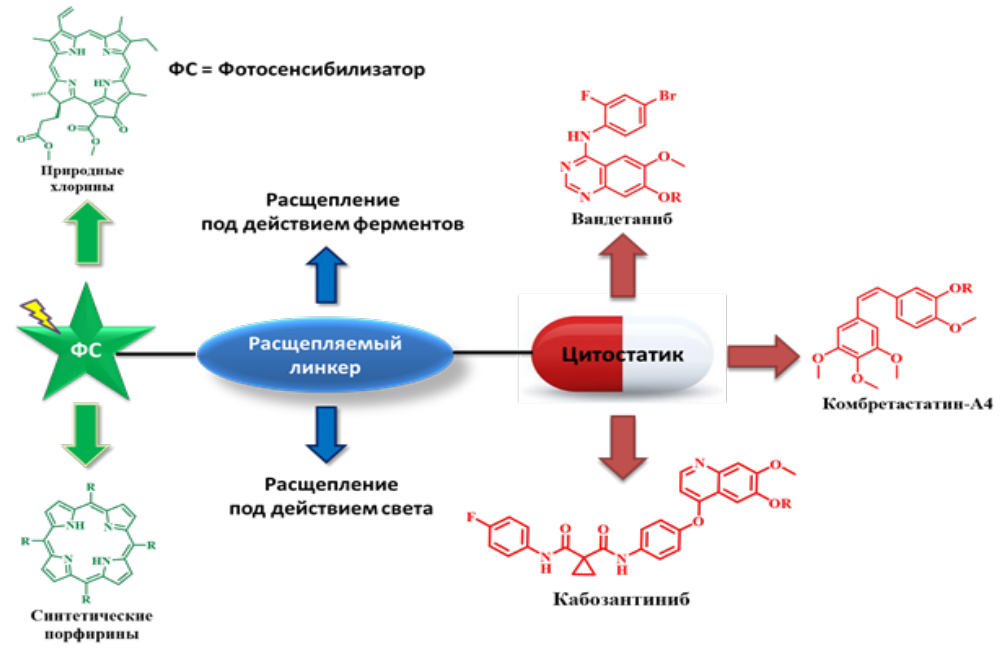

Схема 1

Литература

[1] A. Yu. Fedorov et al, J. Med. Chem., 2019, 62, 11182-11193.

[2] A. Yu. Fedorov et al, Eur. J. Med. Chem., 2018, 144, 740-750. 